\title{
Correction to: Molecular basis of Leigh syndrome: a current look
}

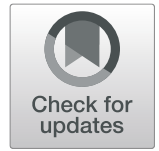

Manuela Schubert Baldo ${ }^{*}$ and Laura Vilarinho

\section{Correction to: Orphanet J Rare Dis (2020) 15:31 \\ https://doi.org/10.1186/s13023-020-1297-9}

The original version of this article [1] unfortunately included an error to an author's name. Author Manuela Schubert Baldo was erroneously presented as Manuela Baldo Schubert.

The author name has been updated in the original article and included in the author list of this Correction article.

Published online: 25 March 2020

\section{Reference}

1. Schubert, Vilarinho. Molecular basis of Leigh syndrome: a current look.

Orphanet J Rare Dis. 2020;15:31 https://doi.org/10.1186/s13023-020-1297-9.

The original article can be found online at https://doi.org/10.1186/s13023020-1297-9

*Correspondence: manuela.baldo@insa.min-saude.pt

Newborn screening, metabolism and genetics unit - human genetics department, Instituto Nacional de Saúde Doutor Ricardo Jorge (INSA), Porto, Portugal

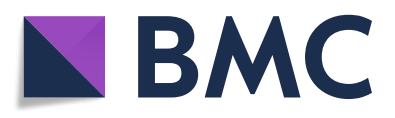

() The Author(s). 2020 Open Access This article is licensed under a Creative Commons Attribution 4.0 International License, which permits use, sharing, adaptation, distribution and reproduction in any medium or format, as long as you give appropriate credit to the original author(s) and the source, provide a link to the Creative Commons licence, and indicate if changes were made. The images or other third party material in this article are included in the article's Creative Commons licence, unless indicated otherwise in a credit line to the material. If material is not included in the article's Creative Commons licence and your intended use is not permitted by statutory regulation or exceeds the permitted use, you will need to obtain permission directly from the copyright holder. To view a copy of this licence, visit http://creativecommons.org/licenses/by/4.0/. The Creative Commons Public Domain Dedication waiver (http://creativecommons.org/publicdomain/zero/1.0/) applies to the data made available in this article, unless otherwise stated in a credit line to the data. 